\title{
PHENOMENOLOGY OF LIFE IN CLINICAL RESEARCH
}

\author{
Fenomenología de la vida en investigaciones clínicas \\ Fenomenologia da Vida em Pesquisas Clínicas
}
Andrés Eduardo Aguirre Antúnez ERIKA Rodrigues COLOMBO JACQUELINE SANTOANTONIO José Tomás OsSa ACHARán Julio CÉsAr MenÉndez Acúrio

\begin{abstract}
Resumo: Apresentaremos uma possível operacionalidade da Fenomenologia da Vida de Michel Henry e seu método em situações clínicas. Neste método investigamos o conceito desenvolvido por Michel Henry nesta fenomenologia denominado corpopropriação e a intuição reflexiva na compreensão e intervenção clínica. É a relação terapêutica em instituições de saúde que é colocada em primeiro plano, tanto nos cuidados a um paciente adulto com transtorno psiquiátrico quanto em grupo com crianças acolhidas. Verifica-se como os terapeutas se corpo-apropriam de seus pacientes e como estes se corpo-apropriam de seus sofrimentos nos cuidados clínicos, bem como o uso das reflexões intuitivas no diálogo. Os resultados nos mostram que um corpo doente pode ser humanizado na relação terapêutica e tem possibilidades de encarnar vivências, ampliando assim a mobilidade afetiva, do sofrer ao fruir de si. No entanto, se a relação não tiver sustentação e continuidade, dificilmente se consegue a estabilidade dessa transformação, mas deixa marcas enraizadas em cada encontro inter-humano.
\end{abstract}

Keywords: Corpopropriação. Michel Henry. Psicoterapia. Atendimento em Grupo. Crianças acolhidas.

\begin{abstract}
We will present a possible operationalization of Michel Henry's Phenomenology of Life and his method in clinical situations. This method investigates the concept developed by Michel Henry in this phenomenology called corpspropriation and the reflexive intuition in the comprehension and clinical intervention. It is a therapeutic relationship in health institutions that is placed In the foreground, both in the care of an adult patient with psychiatric disorder and in a group with sheltered children. It is verified how therapists body-apropriation of their patients and how they body-appropriate their sufferings in clinical care, as well as the use of intuitive reflections in dialogue. The results show that a sick body can be humanized in the therapeutic relationship and has possibilities of embodying experiences, thus increasing the affective mobility, of suffering when enjoying oneself. However, if the relationship does not have support and continuity, it is difficult to achieve the stability of this transformation, but leaves marks rooted in each inter-human encounter. Keywords: Corpspropriation, Michel Henry, Psychotherapy. Group Therapy. Sheltered children.
\end{abstract}

Resumen: Presentaremos una posible operatividad de la Fenomenología de la Vida de Michel Henry y su método en situaciones clínicas. En este método investigamos el concepto desarrollado por Michel Henry en esta fenomenología denominado cuerpopropiación y la intuición reflexiva en la comprensión e intervención clínica. Es la relación terapéutica en instituciones de salud que es colocada en primer plan, tanto en el cuidado a un paciente adulto con trastorno psiquiátrico como en grupo con niños huérfanos. Se verifica cómo los terapeutas se apropian de sus pacientes y cómo éstos se apropian de sus sufrimientos en los cuidados clínicos, así como el uso de las reflexiones intuitivas en el diálogo. Los resultados nos muestran que un cuerpo enfermo puede ser humanizado en la relación terapéutica y tiene posibilidades de encarnar vivencias, ampliando así la movilidad afectiva, del sufrir al goce de sí. Sin embargo, si la relación no tiene sustentación y continuidad, difícilmente se consigue la estabilidad de esa transformación, pero deja marcas enraizadas en cada encuentro interhumano.

Palabras clave: Cuerpopropiación. Michel Henry. Psicoterapia. Terapia em Grupo. Niños húerfanos.

\section{Introduction}

In 2001, Michel Henry lectured a conference for doctors in Portugal and since then we have been working on the extent of his phenomenology of life in interdisciplinarity. On that occasion, Florinda Martins argued the thesis that subjectivity is not extrinsic or a supplement to science, as science satisfies a demand from subjectivity (Antúnez, 2015, p.318). A new, promising affective disposition of life in us as revelation of the other as affect, significantly affecting clinical researches, not only with regards to medicine, but also to psychology, emerged. The patients we worked with have the desire to understand themselves, that is why they seek the therapist. The authors of this paper argue that the terms "objective" and "subjective" are no longer valid in clinical research, as the relationships in the phenomenology of life approach are processes originally affective, whose phenomenality obeys dynamics which precede and establish the subject-object duality itself. In a clinical relationship, and in an investigation thereof, we propose the transcendence of this subjectivity versus objectivity duality, in the interest of the person-person relationship and the affective dialectic revealed in the, and as a, relationship.

If Henry (2000) states that the clinical look is, nowadays, one of the last havens of culture, it is because all objective knowledge is permeated by 
someone who sees. What is seen in a radiography is something other than the objective body, but it interprets the result of this observation for the living, ailing flesh that is the patient. This is also applicable to psychology, for instance, when dealing with serious psychological evaluations. According to Henry (2003), the power and joy of living can be given back to an ailing life (Antúnez, 2015).

We have previously investigated the phenomenality of psychological treatment with an emphasis on the phenomenality of the unpredictable in daily life (Antúnez \& Martins, 2013), which occasionally debilitates and disturbs the human being. Thus, the therapist has with their patient the possibility of responding to the affective transitivity of experiences that occur in a relationship and that always occur in community.

The interdisciplinary work is important to psychology, as it is a means of seeking other knowledge that addresses this unpredictability and the fragility of inter-human phenomena (Antunez, 2015). It is in the "living-life/living-living relationship that the therapist will look for narratives and outcomes of the experiences that disturb the patient" (Antúnez, 2015, p.320). Some works by Henry (2000; 2003; $2009 ; 2012^{\text {a }}$ help us in this interdisciplinarity, showing the operationality of this phenomenology in the medical and health practices, as well as in the clinical practice.

The dialog between patient and therapist occurs via conversations whose rationality is sought not on previous representations that patient and therapist have regarding an event, but on the processing of the experience that "is evidence of itself in its own appearance, which carries within itself the reason of its appearance" (Antúnez, 2015, p.320). It is not only a conversation, but also a living-living contact revealing the invisible in each and between them, that is, there is an impressionality that each of them is deeply touched, through the other's glances, gestures, non-verbal behavior, and presence. The therapist committed to an understanding attitude, of openness to the not knowing and searching for ways out of the obstacles that appear in the life of the patient, which sometimes are reproduced in the therapeutic relationship, adopts an attentive attitude to the knowledge that reveals itself within them, in the encounter, and in the life of the patient.

The daily experiences are in constant change, such as the experiences in each of us, a pure, dynamic uninterrupted motion of life itself, always in relation to the "other". Our focus is to investigate life as it appears in the clinical practice, in each of us and in the relationships. It is important therefore to investigate the person-person relationship, in the first person, in which the "I-you" is the relationship between one "I" and another "I", each responding to the affective modifications in themselves - the self of the patient and the self of the therapist - which are the affective changes in a corporeality that is the living body of each - therapist and patient - and made in the reflective intuitions in both individuals in the relationship. It is this activity of each self
- owning the affective change experienced in their living body - that Henry (1965; 2012 ) calls body-propriation.

We insist on the idea of inverting the understanding of the phenomenon as "an impression in the interior of objectivity, as the representation, evidence and concept, but the representation and objectivity become an impression in the interior of the phenomenality of life of each person" (Antúnez, 2015 , p.320). Thus, we will be attentive to the contingent phenomena the relational life presents us with, particularly in the practice, that are not subject to theoretical processes preceding them. The predominance of the theoretical in the therapeutic phenomenality is impossible, as the phenomenality of the unpredicted "is in itself its own proof in what it is to become and what will happen to it" (Antúnez, 2015, p.320).

Our viewpoint on this method does not negate an intentional phenomenality. On the contrary, it turns to that which, in it, is most primal and fundamental in human relations: that which allows for intentionality is in the life of each of us experienced as pathos. A pathos that establishes the intentional phenomenality itself and exists without its consent, and for that reason it is also often called co-pathos: "it is the phenomenality of the affection of the life of our experiences in co-pathos" (Antúnez, 2015, p. 320). The affective narrative of our intentional living with the life background which effects it is, then, our focus of attention. Therefore, every representation in our minds is closely connected to the affective phenomenalities, which originally constitute us.

It is the passage from suffering to fruition of the affective modalizations in the life of each and every one of us that will be put to the test in this work method. If each patient who seeks us brings with them difficulties they cannot handle, these difficulties would be in relation to others and it will be in a relationship that we will try to resolve such difficulties. Offering in the relationship possibilities of new relations that had not yet existed in the life of those suffering.

The difficulties inside them are experienced in their lives and, as such, are felt in their body. That is why we point out that, with regard to the phenomenology of the body, Henry's (2012a, p.7) intention was to establish "the concrete character of subjectivity showing that our subjectivity is indistinct from our body itself". (...) "If the body is subjective, its nature is contingent on the nature of subjectivity. (...) Life was not to be perceived either as intentionality or transcendence, but by exclusion, as outside itself, outside both of them". Thus, for Michel Henry, corporeality has a key, new place in this conception.

We highlight that the importance of the notion of body-subjectivity to psychology led us to conduct an investigation based on interdisciplinarity and whose operationality will be verified in our clinical cases. To that end, we begin with the question of how Michel Henry defines corporeality. He himself provides an answer: 
Corporality is an immediate pathos defining our whole body, before it emerges to the world. It is from this primal corporeality that it derives its fundamental potentialities, namely, being a force and acting, acquire habits, remembering - in the way in which it does it: outside any representation (Henry, 2012a, p.7).

We can investigate how the corporeality/subjectivity of the therapist behaves in relation to the corporeality/subjectivity of the patient, which forces and actions appear outside representation and, a posteriori, how we can use this representation to understand and deal with the issues presented. The priority is given not only to the representations, but to what the fundamental and primal potentialities of the encounter between pathos, in pathos-with, demand from them.

Henry (2012a, p.8) establishes a dialog with Maine de Biran, philosopher whose work has oddly never been translated within the United States. For Henry, this relates to a deception connected to the essence of Life: "In the invisibility of its night, however, life is restricted to itself. It gives to each, to the unequivocal in their bodies, themselves". Despite the relentlessness of science in acknowledging "the monstrous objectivity of technique", that is what "life's relentless desirte to keep on living" illustrates.

Michel Henry's conception of life invites us to rethink clinical practice, not based on a priori theories, or techniques for handling life's difficulties, but in a setting in which "life [also] may reveal itself. It does not need anything other than itself in order to appear to us; it is a self-givenness, the "primitive fact" (Henry, 2012a, p.8). Thus, we embrace what is revealed in us, in our self-givenness when in contact with somebody, who with their suffering wants to continue to live some other way. "A body which is an 'I'" (Henry, 2012a, p.18) is the center of human reality.

For Henry (2012a, p.18), "the first philosopher and actually the only one, in the long history of human thought, that understood the need to originarily define our body as a subjective body was Maine de Biran, this prince of thought, who deserves to be perceived by us, along with Descartes and Husserl, as one of the true founders of a phenomenological science of human reality". He then indicates the distant relation of this authentic conception and psychology: "A body which is subjective and an ego", summarizing (Henry, 2012a, p.21) Biran's thought.

In the phenomenological assumptions of biranian ontology, Michel Henry shows us that Biran understands the cogito "not as a reflective and intelectual act, but as an action, an effort, a movement" (Henry, 2012a, p.23), focusing on the "subject of reflection or internal apperception" (p.23). Reflection here means "that which does not move towards this world, but turns inwards, and remains by its own side in its distance between it and everything else" (Henry, 2012a, p.24). Thus, it is by expanding on the knowledge of Maine de Biran and citing him that Michel Henry reveals to us a science identified with an existence which is not abstract but real or felt (Henry, 2012a, p.32). For Biran, true metaphysics is a psychology, and it seeks the principles of a psychology, as it, as a science, requires a principle.

In a footnote, Henry (2012a, p.33) states "thus, with regard to life, psychology is contingent; in fact, as a science it is essentially historical". But the science we seek focuses on the affective dialectic in the encounter. The judgements of the psychology, based on Biran's thesis, are judgements based on data as intuitive judgements. They are made based on something that precedes them and is more primitive but is nevertheless apprehensible. This something is the internal apperception of the event. A first intuitive judgement is the one of personal existence (the cogito), which is also a reflective judgement, which, according to Michel Henry, "is not the therapist's privilege, it is a natural judgement" that spontaneously expresses natural life and is a judgement as old as the judgement of our existence (Henry, 2012a, p.34).

\section{Body-propriation}

Kanabus (2014) shows us the many forms in which Michel Henry uses such concept: corps-propriation in La Barbarie, corpspropriation in Phénomenologie de la Vie Tome IV, co-propriation in From Communism to Capitalism and copropriation in The Genealogy of Psychoanalysis. From this article by Benoît Kanabus we paraphrase aspects that are important to the therapist. The therapist must act "employing the internal powers of their body in the sense of effort if they want to achieve a result which is in itself subjective" (Kanabus, 2014, p.106). So that the therapist and the patient will take into account that it is through the internal exercise that change will occur. The patient has "a life that seeks, in its body-propriation of the world, to become a selfhood [ipseity], a uniqueness, by responding to its fundamental needs" (Kanabus, 2014, p.108). And the therapeutic encounter allows this body-propriation by being actively present to the needs of the other, as, according to Henry (2015), we transform the world to a point where it is impossible to contemplate a landscape without seeing in it the effect of a given praxis.

Based on a comparison of the Man-Machine work relation, we will then attempt to revert it to a Man-Man relation: "working with a machine is to inhabit it with your body, to experience your machine in your body, to make the machine an extension of the body" (Kanabus, 2014, p.111). When working with the patient, we must inhabit them with our body, experience them as an extension of ourselves, so as to help them promote that which is not possible in their life. As our sense of effort, to transform. We know that in certain psychopathologies, our body reacts differently from outside this field. Our experience is different for each person we interact with.

When Henry (2012a) uses the term body-propriation he is referring to the body itself which, in 
an embodied and sensorial relation, transforms itself and, in this process, not only transforms the world but also appropriates and transforms itself (Ferreira \& Antúnez, 2014, p.152). Martins (2014, p.58) remarks that "for Michel Henry my body is a body in its own right, or, in accordance with Biran, I am my body - cogito. And as the cogito - defined by the phenomenality of feeling, this is an a priori union: body-propriation."

Body-propriation is the appropriation and control over the powers of the body, which allows the constitution of the Self and of its action in the world (Ferreira \& Antúnez, 2014, p.153). Kanabus (2014, p.109) resorts to Christophe Dejours, who takes up the concept of body-propriation in the work practice to understand the process of subjectification of individuals at work. Such process can occur outside psychoanalysis: "In this case, the subjectification relates to something else, namely the conditions due to which the world (matter, tools, technical objects) can be appropriated by a subject on the one hand, and the ways in which those appropriations takes place (as affective experience of the body, not as cognitive representation) on the other" (Dejours, 2012, p.43). Thus, we can use the concept of body-propriation in clinical investigations of one-on-one and group relationships with the following question: how can we body-appropriate our patients' life and suffering? How can they body-appropriate the therapeutic relationship? To that end, what Christophe Dejours warns us about in an interview given to Kanabus (2015) is very useful; he draws attention to the unfinished bodies of psychotic patients, the difficulties somatizing patients have of appropriating their bodies or psychosomatic cases.

In this investigation, we propose reflecting on how this concept may be understood in the psychotherapeutic treatment of a patient with a psychotic disorder and with regard to children in care seen in group therapy.

\section{Object and method of phenomenology}

The object of phenomenology is not exactly the phenomenon, the apparent, but the act of appearing, the way in which it appears, and it is this object that makes phenomenology different from all other sciences (Henry, 2014, p.39). Thus, a new, infinite field of investigation is revealed (Henry, 2014, p.41), not only to traditional phenomenology but also to clinical psychology itself.

Classical phenomenology has basic principles. First: so much appearance, so much being. As something appears to me, it, at the same time, is; thus, appearing is being. For example, when an image appears, its content does not matter, what matters is that it appears. All its existence and power, the power to appear, is contingent to that. Second: right to things themselves, to what appears in the way in which it appears. It is not the content of the phenomenon, but what makes this content a phenomenon, with its pure phenomenality, that is its appearing. It is the object that constitutes the method. An enlightening question whose phenomenological inversion is proposed by Michel Henry: "Why do we need a method to reach the appearing and knowing it, when the appearing itself reaches us and makes itself known through itself?" (Henry, 2014, p.49).

The principle of principles from Husserl - Paragraph 24 of Ideas I (as cited by Henry, 2014) - is intuition as a phenomenological concept, which refers to the mode of appearing, not to an object. Hence it is a meaning-giving intuition; a mode of appearing is a mode of givenness. The mode in which they give themselves to us is an original givenness, hence the degree of evidence and certainty. Everything I see is a primal givenness which is evident, unlike a memory, as I can be mistaken about it. Thus, the structure of consciousness gives intuition is giving nature through intentionality. The object is visible, placed in front of; the intentionality is this "to make see" that reveals an object. Double meaning: what appears is the object in its own mode of appearing visible to us (Henry, 2014, p.53-55).

However, Henry (2014, p.58) inquires: "Or is there another mode of revelation other than the "to make see" of intentionality - a revelation whose phenomenality is not of the "outside", of this pre-plane of light which is the world?" and states that there is no answer to this question in classical phenomenology. Hence his proposition of a material, not-intentional, concrete phenomenology.

In the practice we use the language in which language itself and verbalization are held in high regard. According to Henry (2014), language is a form of revelation, a manifestation of the self to someone else. It reveals part of the suffering. As for the suffering, "for the one suffering, nothing can attack their suffering. Suffering has no doors or windows, no space outside of it or in it for their escape. (...) There is no possible way out. Between suffering and suffering there is nothing. For the one suffering, as they suffer, time does not exist" (Henry, 2014, p.88).

In Souffrance et Vie, Michel Henry shows us that life and suffering are inseparable. In one of the descriptions on suffering he argues: "Suffering is affected not by something else, but by itself; it is a self-affection in the radical sense that it is affected, and by itself. It is at the same time the thing that affects and the thing affected, the thing that causes suffering and the thing that suffers, indistinctly. It is the suffering that suffers. It is not on the surface of a skin that is not it. Suffering does not feel anything, feeling oneself is always opening oneself to something 'other'. Suffering feels no other, only itself. 'To feel one's own suffering' is an inadequate expression. It presupposes a relation with the suffering." (Henry, 2014, p.88). We remark that the suffering is not related to itself, it suffers itself, hence a phenomenological inversion of the way of thinking of Michel Henry and his not-intentional phenomenology; Life (and suffering) has no intention whatsoever, it is our awareness that seeks a meaning for itself, hence the importance of the practice. 


\section{Operationality or relation between phenomenology and clinical practices}

We will present two clinical situations; one is a one-on-one relationship between therapist and a patient with a psychiatric disorder in a philanthropic public institution; the other is related to group therapy with children in care in a higher education public institution.

To explain these cases with adults and children, and in accordance with the phenomenology of pathos and with the not-intentional phenomenology, a phrase by Michel Henry will echo throughout our exposition: "children and human beings in general make their movements without thinking about them but not, however, without knowing them" (Henry, 2012a, p.72).

\section{Psychotherapy Practice}

How to investigate the relationship in the first person when the matter in hand is the relationship as a $w e$ ? One of the courses we discovered to investigate the relationship in the first person is through exploring that which the therapist feels in the presence of the patient. The therapist feels that which is experienced in each relational moment, thus exploring the intersubjective field, or more specifically how the interpersonal field echoes in them. This approach by the therapist/researcher in relation to an "other" fuels the appearance of important characteristics in the person's affectivity; a "to feel" emerges in the relationship which is pre-thematic and pre-symbolic but experienced in relation or in a two-way interiority that informs us on the pre-reflective aspects of the patient, of their living body itself.

We will present a clinical situation with a patient. He was referred to the Mental Health Division of a philanthropic Public Hospital after an attempted suicide, with the diagnosis of bipolar depression and psychotic episodes.

The first question that caught the attention of the therapist was the young man's eyes; he had a fixed gaze, and the therapist felt an emptiness in it. During the first encounters, his narrative was devoid of feelings and had dark contents. For example, he attempted suicide by piercing his heart area with a knife. The therapist noticed that the young man experienced it without showing any emotions, but with an intense, cold gaze. The patient said to the therapist that the doctors told him that had he inserted the knife a few millimeters to the left he would not be alive at the time of the interview, that he was lucky. The therapist asks how he felt talking about it. The patient answers that describing it was difficult and becomes silent. The patient reiterated that, at that time, it was clear to him that he had to kill himself, and again becomes silent.

The patient says he is alive, but that he came really close to dying. When asked to talk about it, he has difficulty using the representative framework of his intellect and memory but relates that at that time the obligation to kill himself, to commit suicide was lucid. Michel Henry's phenomenology of Life shows us that a human being cannot detach themselves from the life that is in them, they cannot distance itself from it. Christophe Dejours (Kanabus, 2014) notes that, in Henry, a pathway to reflecting on the psychopathology of the denial of the self and of life, the refusal of life, and the distancing from the self, is opened. The young man wanted to kill himself by shoving a knife into his chest, so as to experience a mutilation of his body, maybe to ease his pain.

In this first phase of treatment, he demonstrated a depersonalized relationship with other people, with only a functional nature, devoid of affective and emotional involvement. The themes had delusional and paranoid ideas of persecution, where he stated that other people wanted to do him harm. He also reported episodes of visual illusions and others where he lost the notion of temporality.

The patient reports that once he was at his workplace, when one of the photocopiers began levitating before him. The therapist asked how did he feel and he replied that he was enjoying seeing the machine fly and spin before him. He said he felt no fear and was not startled. The patient believed that his conscience then was so accelerated that he could see advanced math theories. He then noted that he misses this ability he had. He then added that it made his sleep difficult, as he could not sleep, for days he did not notice the hours going by. The therapist asks him whether he misses this and the patient replies positively, on the other hand he believed he frightened people.

It is from this phenomenality of the hallucination that we try to comprehend this young man's human "acting" and with it the essence of a practice which has a new approach and a new basis due to Michel Henry's phenomenology of life (Martins \& Antúnez, 2016). It is as if he was looking for evidence of himself through feeling: "I felt no..." and his mind raced, the primacy of disembodied representation in that moment. However, there is a feeling, he misses: "I miss..." and in the dialog with the therapist he brings a piece of information related to his detachment from other people, the difficulty in establishing contact: "frightened people".

The therapist observed how this changed by following up on the narratives, on what he felt and conveyed and providing room for him to express himself. The young man, in a few sessions, started to manifest emotions, bringing an intense suffering, crying a lot. The psychotherapist was understanding, and did not interfere with his narrative. The relationship had a pre-thematic tone, with the presence of silences. The patient seldom spoke, he needed to be with someone who accompanied him in his suffering, which he hardly shared. It was then that themes related to other significant persons in his family began to appear.

The patient asks himself how could he have tried to kill himself and cries. He justifies it saying that he did it to try to save his daughter's life. As he verbalizes this he realized how wrong he was. He 
realizes that he would have left his daughter to grow up without a father, and that he was only thinking about himself. The therapist watches him intently and notices a feeling of deep frustration, pain and helplessness. He tells that he helps with the housework, with repairs, since he was 12 years old. He says he had to help, as his father drank a lot and his mother was not able to provide for the children by herself. He was the eldest and still helps out. He shows concern with being on leave from work and with the possibility that his daughter would think of him as lazy, someone who does not like to work. He worries about the image he is leaving her. The therapist tells him that he acknowledges that he is going through a really rough patch in his life, but he is coming to therapy without missing sessions to deal with these questions. He tells him that he notices he is brave. The young man agrees and says that he is aware he is taking a time off to recover and rest in order to get better.

In the following sessions the young man was physically closer to the therapist, they greeted with hugs before and after each session. The themes presented started to focus on things other than him, including the "other"; his daughter, for example. Motivations and future projects appeared. At that moment of the therapeutic process, he wished to associate and have projects with other people again, thus seeking to find a new meaning to his life. The therapist notices how themes are now more focused on daily life issues, not only on himself, where the patient's emotional state quickly fluctuated between joy and moments of despondency and deep sadness.

It was remarkable for the therapist to see the appearance of humor during the sessions. In situations where the patient spoke with an unemotional voice at the beginning of the sessions, after a while during the process he was able to be humorous about some experiences that were narrated and experienced with great suffering. The emotional state of the young man was more stable, but he still had physical complaints, such as lack of energy and difficulty sleeping and waking up.

The patient is concerned about the future of society, as he believes it should be dominated by post-modernity's capitalism, but in reality it is the capitalist system coming to an end, where this system does not want to concede and will end human kind. He says he misses taking part in political activism, in political and philosophical discussions, which gave him the feeling of being part of something. He speaks of his doubt on whether they would take him back, as he frightened people and they threw him out. The therapist reiterates the importance of him being part of this group. The young man said he wanted to go back, read and study, that those things were good for him, in addition to take care of his body by playing sports. He shows future perspectives. Such as applying for Enem [Brazilian National High School Examination]. He expresses the certainty of approval, he just needs to organize his schedule and study. The therapist acknowledges these projects and the young man says he is feeling better and that he believes this is due to the therapist's help, who says he also believes he is better, but he thinks it is due to their relationship, not just him the therapist.

We saw how the therapist moved from the use of the first person to the use of the pronoun "we". The patient regained his autonomy and started coming to the sessions alone, as he was being accompanied by his mother, who insisted on bringing him. He regained the desire to be integrated with society. This partial report of the therapeutic work spanned 15 months and involved two 40-day hospitalizations, where we considered the progress achieved.

In the clinical relationship the therapist provided the patient with help in the body-appropriation of his suffering in an embodied manner. Acceptance and understanding in a relationship that takes into account the affective experience of the body, not as cognitive representation, but as an appropriation of the relational subjectification. This qualitatively impacts the regaining of relational potentialities and the search for transformation and a meaning to his life.

We see in the relationship in acute moments the intense symptomatology that culminated in relational isolation. The lack of understanding from people with whom he associated with seemed to lead him to an affective isolation. As he became closer to the therapist the intensity of his symptomatology decreased. There was in him a direct proportionality between how he felt his relational experiences and how he perceived himself: he showed the possibility of perceiving the "other" as a person, someone with a unique nature, thus he experienced his ipseity in his relationships with dynamism and continuous transformation.

It was in the encounter that the possibility of transformation of the modalities of his suffering was augmented. The suffering can thus be transformed in the relationship outside of it, body-appropriated by the person we are treating. However, it is also important to pay attention to how the therapist body-appropriated themselves and is enriched as a therapist as they accompany him in his experiences. Not only the patient is touched in the core of his being, but also the therapist, due to the power of the affective dialectic experienced at the moment of the encounter, in this real, deep relationship established and developed with every encounter.

\section{Group Therapy}

This was an extension-program project investigating the possibility of a Free-Expression Drawing Workshop with children in a Shelter Home. This investigative work is based on the doctoral dissertation presented by Ternoy (1997), in its turn based on his twenty-year relationship with psychiatric patients in a Free-Expression Drawing Workshop. The observation and analysis of Michel Ternoy's research is based on Minkowski's phenomenon-structural method. The project was implemented in Bra- 
zil at the Center for Psychosocial Support - CAPS at UNIFESP (Santoantonio, 2014), in the treatment of adult psychiatric patients, and is in operation since 1999. In 2013, the pilot project with children in care was introduced.

The group activity takes place as follows: at a given time, patients are informed that the workshop will begin and they may then go to the location to participate. The materials are sheets of paper, preferably of a high grade and quality, colored pencils, wax pencils, erasers, ruler etc. Everyone draws, including the therapists. Each person draws a drawing, for about an hour, and the drawings are then pinned to a pinboard.

After that, everyone faces the board and a dialog begins. Therapists invite patients to share what they felt and/or were thinking while creating their drawings. They start to talk about their own creation and also the creation of others. And so on.

In the psychiatric context, we have noticed through the years that patients enjoy this activity and want to participate. Not only for the techniques and procedures, but also for the way in which they are treated and respected in their creation and expression, in a most honest and simple creation of an image or drawing and in which they verbalize from the image.

There are many perspectives in psychology that interpret the meaning of the drawing in light of psychoanalytic and psychodynamic theories. What we want to know is what the creator reveals of the meaning of their own work, and not its interpretation. The intention is not to create a work of art. Our intention is to allow for an expression through images. Both the image and its narrative reveal a lot about the manifestation of that person's expression of life at that moment.

In 2008-2010, a research was conducted, funded by the $\mathrm{CNPq}^{1}$ [National Council of Scientific and Technological Development], with adult patients and in 2013-2014 we conducted a Pilot Project to investigate this modality of treatment in drawing workshops with children in a specific Shelter Home in São Paulo ${ }^{2}$.

Some of the children studied in the morning and some in the afternoon. The ones free at the given time came to the workshop, which always took place at the same time. No child was forced to participate; they were invited and the ones interested came. Some sessions had ten children, but the overall average was five children per session. Age ranged between four and sixteen years. There was no age limit and it was very interesting to see the interaction between children of different ages, particularly to be able to understand their dynamics.

Unlike adult patients in a CAPS, the children knew each other and lived together full time. They expressed in the workshop what they experienced outside it. Our goal with these children was

\footnotetext{
1 Funding: CNPq, process 400163/2007-1. Approved by Plataforma Brasil and Ethics Committee - Human Beings of the Psychology Institute of Universidade de São Paulo [São Paulo University].

2 Discipline 4702893 Supervised Internship I (Graduate Program) in the Psychological Clinic Durval Marcondes, in the Psychology Institute of Universidade de São Paulo.
}

to create a place of acceptance, so that they could somehow regain their individuality, subjectivity or personhood - which can get lost when they have to share everything in the shelter; clothes, rooms, nothing was theirs alone - in the encounter with the therapists.

We also wanted to allow them to express themselves. In internships in shelters it is usual to be told by the caretakers that they do not have access to the children's history. Even the person in charge who brought the children to the workshop did not have access to the medical charts. We noticed an "unsaid" in the shelter.

The pilot project was active for a year and a half, after which it ended due to a long period of strikes and issues with transportation from the Shelter Home, which was unable to bring the children to the public University. We had the practical experience in which our focus was what we felt and observed in our experiences. With the CAPS adults, everyone that drew and talked about the creations did it in a voluntary basis. However, in our first session with the children, we realized that this second part would not be possible.

After that, we abandoned that idea and began talking with an open-ended approach, while drawing. We would see the children doing something interesting and promptly start a dialog about their actions. From then on everything had a better flow, and interesting things started to appear spontaneously. Sessions became calmer, without us trying to organize the children around the board.

The material produced opened the possibility of a phenomenological comprehension of those children's experiences, based on the individual semantics they introduced, in a spontaneous and peculiar manner. We will now present some specific points that strongly marked this experience. We observed that the children were agitated, particularly at the start and at the end of the session. They came running and also left running. After the first encounter the children already knew what would happen and helped us organize the room. In the earlier sessions, they ran and jumped a lot. In one of them one of the girls, the most agitated one, suddenly climbed on the shelves, but the therapists saw it and brought her down before she fell. They became calmer over time.

The need for contact was evident. They came running and hugged the therapists, wanting to sit on their laps and asking for help with their drawings. We notice they had a need for something, and they were communicating in their own way that it was important to them and to the dynamics of what was taking place between the people involved.

In the first session there were two brothers, one aged 4 and the other aged 7 . The therapist drew a dragon and painted it green. In the drawing, the dragon was sleeping and did not look like a menacing dragon. When the younger brother saw it, his eyes widened and he said "could you draw one for me?" And his brother: "I want one too!" And the therapist thought "how am I going to draw a bunch of dragons now?" And then she said: "look, you 
each draw your own dragon. You can try looking at and copying mine and it will be cooler, because each of you will be creating something your own way, not mine." The younger brother then wanted to place a sheet over the drawing to copy it, but the Canson sheet was too thick and was not transparent. In the end, they agreed to try to copy and to draw each his own drawing.

At the end of this session, the therapists pinned the drawings to the pinboard and the older brother spoke about his: "my dragon is not as good as the miss's, but it is her dragon's baby, so the miss is my mother!" Another boy, also aged seven, sat on the therapist's lap and said: "no, she is my mother!" And then both boys began arguing about it, while a girl was running and doing handstands between them.

On this first session the caretaker entered the room and the therapists let her participate in the workshop - she afterwards decided she did not want to enter the room anymore - and it was she who calmed down the children so that the therapists could finish the session.

It also caught our attention the signs of violence that the children had in their bodies. There was a boy, the one who sat on the therapist's lap on the first day, with arms scarred by cigarette burns inflicted by his own parents. Other children also had marks, such as cuts and scrapes from playing. And some had the habit of picking scabs until they would bleed.

Over time, the therapists noticed that the children were somehow more open to talking of things they did not talk about in the beginning. They started making comments about their families and about things that happened in the shelter home.

There was a loving, affectionate, but at the same time agitated, 7-year girl, who told us that she had already been adopted, but was later returned. So the therapist asked "do you know why they returned you?" She replied: “well, miss, I was always jumping up and down and being noisy and could not sit still". The therapist replies: "well, children are like that, aren't they?" So she paused, looked at the therapist and said "I like you, miss!" and continued drawing, as if nothing had happened.

The older children were more reserved; the young ones could comment on things more easily - in spite of the fact that we usually have the impression that a younger child would find it more difficult to deal with the type of violence and suffering they went through. It seemed as if the older children were more closed with regard to what they probably experienced.

It was also observed that the children enjoyed sharing their creations. They would many times write the name of another child who was not present and say "this one I'll take to so-and-so", "this one I made for so-and-so". If any children missed the workshop for any reason, to go to a doctor for instance, they would say "so-and-so didn't come today, but I'll take this drawing to them". It was clear that they wanted to share what they were experiencing in there.
In light of everything we observed, we think it is relevant, in a dialog with Henry's work, to present some excerpts from his work for a reflection on what we experienced in the workshop with the children in care. "We are dealing with the concept that the individual is formed by the interiority of the world lived in which the experience with the 'other' is not a secondary consideration, but rather essential, fundamental" (Santoantonio, 2014, p.265)

According to Henry (2009, p.113) "the self [moi] represents itself, projects itself before itself and involves itself in its own representation in a much more essential way, precisely due to an essential need: as in its own representation every possible thing representable is represented to the self [moi] which represents itself, before itself, in its possessions [par-devers lui]. Therefore, the self [moi] is assumed in any representation not a posteriori, as the object it discovers, but a priori, as part of the formation of the field in which the discovery will be made, to the extent that such field is created precisely as if thrown by it, before it, in its possessions [par-devers lui] - to the extent that this back-reference to the self [moi] is, therefore, identical to the structure in this field and to its opening". Thus, the self of the children were involved in the relationship in an essential way; they represent themselves, manifest their lives and the possibilities they need.

Michel Henry states:

It would be a grave mistake to perceive painting and art in general as means of expressing a content different from them. When it became life, replacing objects, it still precedes its artistic expression, eventually making it as useless as when recopying an already present world. It is true that our life matters to us and interests us more than this world, even if it is by this extraordinary property which defines it: to feel oneself, experience oneself - that happiness with things so cruelly deficient. To such an extent that they remain silent and unsatisfied under the gaze of man, waiting for him to grant them this presence which they seem to have by themselves, but, in reality, are due only to subjectivity, to the self-experiencing in which everything experiments itself and becomes alive (Henry, 2012b, p.155).

Further ahead, he states:

Prior to being the luminous dream of yet unborn worlds and their ravishing surge, imagination is the history of subjectivity itself, the expansion of its pathos, the motion through which each sonority awakens one in itself and then another. Thus they rise in succession to fulfill their culture in all the potentialities buried in the human soul, the treasure of their innate ideas, the infinity of their power of feeling, of reaching happiness (Henry, 2012b, p.162). 


\section{Final considerations}

To be able to recover the individuality before the community and to be able to rethink the political dimension and the dimension of civic consciousness are not conflicting powers; they are co-constitutive powers (Martins ${ }^{3}, 2016$ ). If the child did not experience a family, they can have the experience of familiarity and closeness with the therapist. In this relationship the child can experience in a positive light the affective narrative with the other self. In the phenomenology of touch the phenomena of "to touch" and "to be touched" co-constitute themselves, with the dialectic of the affects being this co-constitution. The individual and the social are not opposed, as the former is essentially social.

The one-on-one therapy and the group therapy reflected and operationalized by the method of Michel Henry's phenomenology show us that there is no fundamental need of a method to reach for the "appearing" before us, as such "appearing" comes to us and makes itself known by itself, with its presence and verbal expressions. The mode of appearing is distinct from focusing on an object, hence the meaning-giving intuition is a mode of givenness which needs to be observed, cared for and discussed in the practice. In addition to what is revealed in the visible before us through intentionality, there is another mode of revelation, the non-intentionality, that which is invisible and is not in the exteriority, but in the life which "is" in each of us.

In the practice we use both the non-verbal and the verbal dialog; both reveal the manifestation of the lives that meet. The question of temporality is placed in another plane, since for the one suffering time does not exist (Henry, 2014).

Thus we verified how the therapists body-appropriated their patients, adults and children alike, their sufferings in the therapeutic care, how they used intuitive reflections in the dialog and encounters and how we presented the occurrences of the relational affective modalities. These results showed us the potentialities that the phenomenological method created by Michel Henry, operationalized in the clinical relationships, can boost the potential humanization of an ailing body in the relationship, and has the potential to glimpse the embodiment of experiences, beyond a functional and biological body, thus expanding the affective mobility, from suffering to fruition of the self. However, caution is warranted, as such results are not definitive, since if the relation is not supported and continuous for a period needed by the patient(s), it will be difficult to achieve stability in transformations, even though every inter-human encounter, not only those deemed therapeutic, will always leave deep-seated impressions. Support for translation FAPESP process n.2016/23681-1

3 Personal communication available at https://www.youtube.com watch? $v=v I G u o 15 y$ Ys4\&list=PLUPuVFeR5HFwgWtFI9p-9dSU5cFrKzErO\&index $=7$

\section{References}

Antúnez, A. E. A. (2015). Histórico das relações entre filosofia e medicina no curso de Michel Henry em Portugal e as relações com a psicologia clínica. Psicologia USP, 26 (3), 318-322.

Antúnez, A. E. A., \& Martins, F. (2013). Acompanhamento terapêutico: vinculação dos fenômenos contingentes e da vida privada. Atravessar, 1(2),19-26.

Dejours. (2012). Trabalho Vivo - Tomo I - Sexualidade e Trabalho. Brasília: Paralelo 15, p.43.

Ferreira, M.V.; \& Antúnez, A.E.A. (2014). O corpo na clínica da modalização do afeto. Humanística e Teologia, 35(2); pp. 145-162.

Henry, M. (1965). Philosophie et phénoménologie du corps: essai sur l'ontologie biranienne. Paris: PUF.

Henry, M. (2000). Incarnation: Une philosophie de la chair. Paris: Seuil.

Henry, M. (2003). Souffrance et vie. Em M. Henry, Phénoménologie de la vie I (pp.143-156). Paris: PUF.

Henry, M. (2009). Genealogia da Psicanálise: o começo perdido. (R.V. Marques, Trad.) Curitiba: Editora UFPR, p.113.

Henry, M. (2012a). Filosofia e fenomenologia do corpo. Ensaio sobre a ontologia Biraniana. (L. P. Rouanet, Trad.) São Paulo: É Realizações.

Henry, M. (2012b). Ver o Invisível - Sobre Kandinsky. (M. Rouanet, Trad.) São Paulo: É Realizações, p.155-162.

Henry, M. (2014). Encarnação - uma filosofia da carne. (C. Nougué, Trad.) São Paulo: É Realizações.

Henry, M. (2015). Phénoménologie de la vie $V$. Paris: PUF

Husserl, E. (1950). Idées Directrices pour une Phénoménologie, t. I. (P. Ricoeur, Trad.) Paris: Gallimard, p.78.

Kanabus, B. (2014). O conceito de corpopropriação em Michel Henry e Christophe Dejours. Humanística e Teologia, 35:2, 101-113.

Martins, F. (2014). A volúpia e o incômodo na configuração dos saberes e da cultura. Em: A. E. A. Antúnez, F. Martins \& M. V. Ferreira (Orgs.), Fenomenologia da vida de Michel Henry - Interlocuções entre filosofia e psicologia (pp.47-80). São Paulo: Editora Escuta.

Martins, F., \& Antúnez, A. A.A. (2016). Michel Henry: Sense of self and hallucination. Estudos de Psicologia (Campinas), 33(3), 425-430.

Santoantonio, J. (2014). O Ateliê de Pintura de Livre Expressão: relato de um modelo de intervenção articulado com a Fenomenologia da Vida de Michel Henry. Em A. E. A. Antúnez, F. Martins \& M. V. Ferreira (Orgs.), A fenomenologia da vida de Michel Henry - Interlocuções entre filosofia e psicologia (pp.253272). São Paulo: Editora Escuta. 
Ternoy, M. (1997). Rorschach, rêve éveillé et expression grapho-picturale dans l'étude phénoméno-structurale des hallucinations (Tese de Doutorado). Université de Lille III, Lille, France.

Andrés Eduardo Aguirre Antúnez - Professor Livre-Docente do Departamento de Psicologia Clínica, Instituto de Psicologia, Universidade de São Paulo. Membro do GT Psicologia e Fenomenologia - ANPEPP. Co-coordenador do Núcleo de Pesquisas e Laboratório Prosopon. Endereço Institucional: Av. Professor Mello Moraes, 1.721 Cidade Universitária, São Paulo/SP - CEP: 05508-030. E-mail: antunez@usp.br

Erika Rodrigues Colombo - Mestranda do Programa de Pós-Graduação em Psicologia Clínica, Instituto de Psicologia, Universidade de São Paulo. Membro do Núcleo de Pesquisa e Laboratório Prosopon. Endereço Institucional: Av. Professor Mello Moraes, 1.721 - Cidade Universitária, São Paulo/SP - CEP: 05508-030. E-mail: erika.colombo@ usp.br

Jacqueline Santoantonio - Doutora em Ciências, psicóloga do Centro de Atenção psicossocial CAPS UNIFESP. Membro do Núcleo de Pesquisa e Laboratório Prosopon. Endereço: Rua Botucatú, 723. CEP: 04023-062. São Paulo. E-mail: jacqueline.santoantonio@uol.com.br

José Tomás Ossa Acharán - Doutorando do Programa de Pós-Graduação em Psicologia Clínica, Instituto de Psicologia, Universidade de São Paulo. Bolsista CAPES. Membro do Núcleo de Pesquisa e Laboratório Prosopon. Endereço Institucional: Av. Professor Mello Moraes, 1.721 - Cidade Universitária, São Paulo/SP - CEP: 05508-030. E-mail: tomas.ossa@usp.br

Julio César Menéndez Acurio - Psiquiatra. Faculdade de Ciências Médicas da Santa Casa de São Paulo. Membro do Núcleo de Pesquisa e Laboratório Prosopon. Endereço Institucional: Rua Doutor Cesário Motta Júnior, 61 - Vila Buarque, São Paulo - SP, 01221-020. E-mail: dr.julioacurio@gmail.com

Received on 12.12.2016

First Editorial Decision on 03.09.2017

Accepted on 10.08.2017 